\title{
Thallium Concentration in Lake Trout from Lake Michigan
}

\author{
T.-S. Lin, ${ }^{1}$ J. Nriagu, ${ }^{2}$ X.-Q. Wang ${ }^{2}$ \\ 1 Department of Environmental Engineering and Health, Yuanpei Institute of Science \\ and Technology, Hsih-Chu, Taiwan 300, Republic of China \\ ${ }_{2}$ Department of Environmental Health Sciences, School of Public Health, University \\ of Michigan, 109 Observatory Street, Ann Arbor, MI 48109, USA
}

Received: 8 November 2000/Accepted: 7 August 2001

Chronic poisoning by thallium appears to be a phenomenon associated with growing environmental pollution (Malbrain et al. 1997; Chandler et al. 1990; Zhou and Liu 1985). The toxicity of thallium to mammals is similar to that of mercury but higher than that of lead, cadmium, copper and zinc (Manzo et al. 1989; Wallwork-Baber et al. 1985; Zitko 1975). Thallium compounds are remarkably toxic to human beings, the lethal dose ranging from 0.5 to $1 \mathrm{~g}$ for a single ingestion (Mulkey et al. 1993; Manzo et al. 1989; Zitko 1975). The concentrations of total dissolved thallium in waters of the Great Lakes exceed those of mercury (Lin et al. 1999; Mason et al. 1997), and the little available information suggests that the levels in aquatic biota are much higher that those of lead, cadmium and mercury (Lin and Nriagu 1999). There are currently few reliable data on thallium levels in Great Lakes fish (Heit et al. 1981; 1985). This report presents the data (whole fish) for samples of lake trout from Lake Michigan. The results are used to estimate the dietary intake and assess the potential risk for people who consume large quantities of fish from the Great Lakes ecosystems.

\section{MATERIALS AND METHODS}

This study used a Milli-Q Plus water system (Millipore Corp., Bedford, MA) to generate ultrapure water for the experiments. Nitric and hydrochloric acids (Fisher Scientific) of two different grades, technical and trace metal-free, were employed in the experiments. Technical grade acid was only employed in the labware cleaning processes while trace metal-free grade acid was utilized in both the final rinsing of the labware and in preparing all the standard solutions. In order to minimize possible contamination, all labware was cleaned following a nine-step procedure involving acetone soaking and multiple acid leaching described by Nriagu et al. (1993). A stock solution of Tl(I) $(1000 \mathrm{mg} / \mathrm{L})$ was purchased from Perkin-Elmer to prepare the appropriate concentrations of $\mathrm{Tl}$ standard solutions. Lake trout samples were collected from three areas (Sheboygan, Sturgeon and Saugatuck) in Lake Michigan during the Spring, Summer and Fall of 1994 and 1995. The age of each fish was determined by counting the year ring on the fish scales. Whole fish samples were ground and stored in glass jars at $4{ }^{\circ} \mathrm{C}$ until analyzed. Aliquots of the fish samples were digested with $10 \mathrm{~mL}$ of trace-metal free grade concentrated nitric acid in microwave digestion bombs whose operating conditions were controlled as follows: Heating/digestion time: 25 minutes; temperature: $<108{ }^{\circ} \mathrm{C}$; ressure, 100 atmospheres. The leachate was filtered if it was cloudy or had some residual 
Table 1. Thallium content in lake trout (wet weight, $n=37$ )

\begin{tabular}{|c|c|c|c|c|}
\hline Sample ID & Fish Age (year) & "Weight(g) & Growth Factor & $\mathrm{Tl}(\mathrm{ng} / \mathrm{g})$ \\
\hline 940239003 & 12 & 5124 & 427.0 & 69.9 \\
\hline 940239004 & 9 & 3474 & 386.0 & 276.0 \\
\hline 940239008 & 6 & 1031 & 171.8 & 231.2 \\
\hline 940239010 & 6 & 1307 & 217.8 & 127.0 \\
\hline 940239012 & 4 & 455 & 113.8 & 496.9 \\
\hline 940239014 & 4 & 373 & 93.3 & 83.5 \\
\hline 940239015 & 5 & 836 & 167.2 & 45.0 \\
\hline 940239019 & 12 & 4296 & 358.0 & 231.7 \\
\hline 940239043 & 4 & 475 & 118.8 & 63.5 \\
\hline 940248014 & 4 & 1043 & 260.8 & 84.1 \\
\hline 940248015 & 4 & 892 & 223.0 & 210.8 \\
\hline 940248041 & 14 & 5333 & 380.9 & 10.7 \\
\hline 940248044 & 10 & 4939 & 493.9 & 95.0 \\
\hline 940248050 & 6 & 2484 & 414.0 & 44.1 \\
\hline 940248053 & 4 & 997 & 249.3 & 110.6 \\
\hline 940248057 & 2 & 211 & 105.5 & 119.3 \\
\hline 940248058 & 13 & 6218 & 478.3 & 229.8 \\
\hline 940248061 & 8 & 4343 & 542.9 & 27.1 \\
\hline 940248067 & 6 & 3364 & 560.7 & 325.3 \\
\hline 940248071 & 3 & 951 & 317.0 & 274.1 \\
\hline 940248072 & 3 & 928 & 309.3 & 239.9 \\
\hline 950224001 & 15 & 8371 & 558.1 & 175.2 \\
\hline 950224021 & 11 & 5378 & 488.9 & 60.0 \\
\hline 950224026 & 6 & 3390 & 565.0 & 309.0 \\
\hline 950239052 & 8 & 2968 & 371.0 & 69.9 \\
\hline 950239067 & 14 & 6785 & 484.6 & 65.0 \\
\hline 950239071 & 11 & 4762 & 432.9 & 150.7 \\
\hline 950239073 & 8 & 2951 & 368.9 & 127.6 \\
\hline 950239076 & 5 & 1633 & 326.6 & 70.3 \\
\hline 950239081 & 4 & 445 & 111.3 & 9.8 \\
\hline 950248002 & 8 & 3600 & 450.0 & 49.1 \\
\hline 950248017 & 2 & 79.6 & 39.8 & 112.8 \\
\hline 950248018 & 9 & 3923 & 435.9 & 88.4 \\
\hline 950248028 & 4 & 1340 & 335.0 & 52.3 \\
\hline 950248030 & 6 & 2598 & 433.0 & 336.2 \\
\hline 950248031 & 7 & 3322 & 474.6 & 58.5 \\
\hline 950248032 & 1 & 79.6 & 79.6 & 183.3 \\
\hline Average & & & & 140.8 \\
\hline Standard Deviation & & & & 110.5 \\
\hline
\end{tabular}




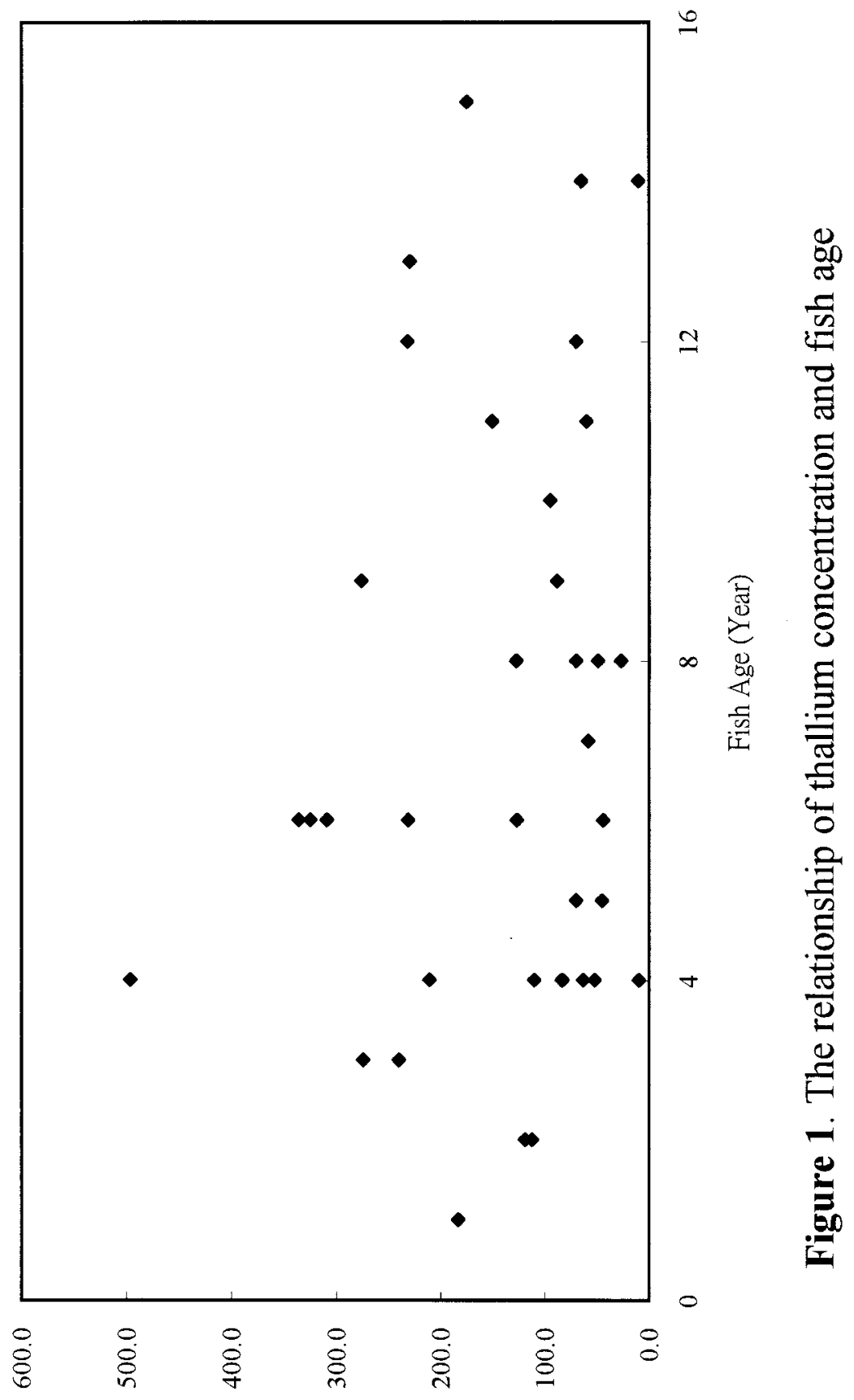

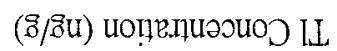


solids. A Perkin-Elmer 4100ZL graphite furnace atomic absorption spectrometer with a Zeeman background corrector was employed for the final determination of thallium. The analytical conditions of graphite furnace atomic absorption spectroscopy for thallium were: wavelength, $276.8 \mathrm{~nm}$; low slit, $0.7 \mathrm{~nm}$; pretreatment temperature, $400^{\circ} \mathrm{C}$; atomization temperature, $1200^{\circ} \mathrm{C}$. The method detection limit was $0.2 \mathrm{ng} / \mathrm{g}$. Approximately $30 \%$ of the runs were replicates designed to ensure the quality of the analytical procedure.

\section{RESULTS AND DISCUSSION}

The average concentration of thallium in 37 lake trout samples was determined to be $140.8 \pm 110.5 \mathrm{ng} / \mathrm{g}$ wet weight (Table 1) and is similar to reported values for brook trout, white sucker and yellow perch in the Adirondack lakes, USA (Heit 1985). Assuming that the dry weight concentration of thallium in biota is ten times higher than the wet weight concentration (Table 1), the dry weight concentration of thallium in lake trout is estimated to be approximately $1.5 \mathrm{mg} / \mathrm{kg}$ The bioaccumulation factor (BF) of thallium in lake trout calculated to 10000 , using an average thallium concentration in Lake Michigan water of $14 \mathrm{ng} / \mathrm{L}$ (Lin and Nriagu 1999). The BF is significantly higher that the $27-1430$ determined in a 300-hour experiment using juvenile Atlantic salmon (Zitko et al. 1975). The relation between thallium concentration in a lake trout and its growth (Figure 1) can be analyzed using a simple regression model. A significant correlation was found between the growth factor (defined as fish weight/fish age) and thallium concentration $(p=0.055)$. Although the highest concentrations of thallium can be expected in the larger, older fish, the value observed seems to vary largely. The variation could not be defined by our limited observation.

Consumption of fish from the Great Lakes is always of some concern because of the high levels of pollutants they contain (Courval et al. 1996; Foran et al. 1989). The consumption advisories for fish from the Great Lakes are generally based on PCB and mercury levels in the fish and rarely consider contaminants such as thallium (US EPA 1997). Simple calculations based on our data suggest that this may be a serious oversight. The acceptable daily intake (ADI) for thallium has been estimated at $0.2 \mu \mathrm{g} / \mathrm{kg}$ or $14 \mu \mathrm{g} / 70 \mathrm{~kg}$ (Ewers 1988). The Reference Dose (RfD) for thallium suggested by the U.S. EPA (1992) provides a more cautious value $(0.07 \mu \mathrm{g} / \mathrm{kg} / \mathrm{day}$ or $5 \mu \mathrm{g} / 70 \mathrm{~kg} / \mathrm{day})$ for protecting the public from chronic thallium poisoning. The estimated daily dietary intake of thallium by the U.S. population is around $7 \mu \mathrm{g} / 70 \mathrm{~kg}$ (U.S. DHHS 1992), which is one half the ADI.

Assuming a regular consumption of four to eight fish meals per month (one meal $=230 \mathrm{~g}$ of flesh), which is considered typical for anglers (Denis et al. 1997), the estimated average daily thallium intake is $12 \sim 16 \mu \mathrm{g} / 70 \mathrm{~kg}$; this value is comparable to the ADI. However, approximately $15 \%$ of the angler population is believed to consume almost twice as much fish as the average angler (Courval et al. 1996). Estimated thallium intake by the high fish consumers is over 20 $\mu \mathrm{g} / 70 \mathrm{~kg} / \mathrm{day}$, and may place them at risk for chronic thallium poisoning. This report clearly calls for a detailed assessment of the risk of chronic thallium poisoning that may be associated with consumption of fish from the Great Lakes.

\section{REFERENCES}

Chandler HA, Archbold, Gibson JM, O'Callaghan P, Marks JN Pethybridge RJ

(1990) Excretion of a toxic dose of thallium. Clin Chem 36:1506-1509.

Courval JM, DeHoog JV, Holzman CB, Tay EM, Fisher L, Humphrey HEB, 
Paneth N, Sweeney AM (1996) Fish consumption and other characteristics of reproductive-aged Michigan anglers - A potential population for studying the effects of consumption of Great Lakes fish on reproductive health. Toxicol Ind Health 12:347-359.

Denis G, Sonia B, Marc T, Pierre A, Jean-Francois D (1997) Health risks related to the consumption of sportfish from St. Lawrence River. Proceeding of Health Conference, Montreal, Canada. May 12-15, p48.

Ewers U (1988) Environmental exposure to thallium. Sci Tot Environ 71:285-292.

Foran JA, Cox M, Croxton D (1989) Sport fish consumption advisores and projected cancer risks in the Great Lakes basin. American J Pub Hlth 79:322-325.

Heit M (1985) Concentrations of potentially toxic trace elements in the muscle tissue of fish from acidic and circumneutral Adirondack lakes. In "Proceedings of the 5th International Conference on Heavy Metals in the Environment" V(I):655-657. Toronto.

Heit M, Klusek C, Baron J (1984) Evidence of deposition of anthropogenic pollutants in remote Rocky Mountains lakes. Water Air Soil Pollut 22:4003-416.

Heit M, Klusek C, Burke JC (1981) Anthropogenic trace elements and polycyclic aromatic hydrocarbon levels in sediment cores from two lakes in the Anirondack acid lake region. Water Air Soil Pollut 15:441-464.

Lin TS, Nriagu J (1999) Thallium speciation in the Great Lakes. Environ Sci Technol 33:3394-3397.

Malbrain MLNG, Lambrecht GLY, Zandijk E, Demedts PA, Neels HM, Lambert W, De Leenheer AP, Lins RL, Daelemans R (1997) Treatment of severe thallium intoxication. Clin Toxicol 35:97-100.

Manzo L, Sabbion E (1989) Thallium. In: Seiler HG, Sigel H (ed) Handbook on Toxicity of Inorganic Compounds, Chapter 62 Marcel Dekker Inc., New York

Mason RP, Sullivan KA (1997) Mercury in Lake Michigan. Environ Sci Technol 37:942-947.

Mulkey JP, Oehme W (1993) A review of thallium toxicity. Vet Hum Toxicol 35:445-453.

Nriagu JO, Lawson G, Wong HKT, Azcue JM (1993) A protocol for minimizing contamination in the analysis of trace metals in Great Lakes waters. J Great Lakes Res 19:175-182.

U.S. DHHS (1992) Toxicological profile for thallium. U.S. Department of Health \& Human Services. Agency for Toxic Substances and Disease Registry. Atlanta, GA

U.S. EPA (1997) Supplementary fish consumption advisory for Michigan's Great Lakes waters 1997. (http://www.epa.gov/region5/fish). Environmental Protection Agency Region 5. Chicago. IL.

U.S. EPA (1992) Drinking water criteria document for thallium. Environmental Protection Agency. Washington D.C.

Wallwork-Barbe, MK, Lyall K, Ferenbaugh RW (1985) Thallium movement in a simple aquatic ecosystem. J Environ Sci Health A20:701-720.

Zhou D, Liu D (1985) Chronic thallium poisoning in a rural area of Guizhou province, China. J Environ Hith 48:14-18.

Zitko V (1975) Toxicity and pollution potential of thallium. Sci Tot Environ 4:185-192.

Zitko V, Carson WV, Carson WG (1975) Thallium: occurrence in the environmental and toxicity to fish. Bull Environ Contam Toxicol 13:23-30. 